\title{
The use of the model for determining potato (Solanum tuberosum L.) tuber distribution in the soil
}

\author{
Rajko BERNIK ${ }^{1}$, Bojan GOSPODARIČ ${ }^{2}$, Jošt POTRPIN ${ }^{3}$, Uroš BENEC ${ }^{4}$
}

Received April 04, 2017; accepted August 09, 2017.

Delo je prispelo 04. aprila 2017, sprejeto 09. avgusta 2017.

\begin{abstract}
The paper focuses on the testing of a model for determining the distribution of potato tubers in the soil. Analytical testing of the model was performed at the laboratory of the Biotechnological Faculty (University in Ljubljana) in 2015 and in the same year, the model was tested in practice on a field owned by the company Zeleni Hit d.o.o. in Ljubljana. After the laboratory testing, the results were analyzed and additional steps were taken to expedite field measurements. To optimize the determination of the distribution of potato tubers in the soil, the program was upgraded to include threedimensional data acquisition. This allows accurate determination of the horizontal, vertical and longitudinal spans of the distribution of tubers in the soil. Specifically, the program calculates the shape of the tubers, vertical cover of tubers with soil and their minimum distance from the left and right edges of the ridge. The program also locates the center of the tubers, which is a key parameter (along with tuber mass) for determining the area of the tuber cluster. The laboratory testing of the model revealed successful data processing of the program and adequate precision analytics. The testing of the model in the field on Arizona potato variety revealed that the model includes all the data necessary for further processing. Based on the calculated data, it can be assumed with great certainty that the model enables the acquisition of all necessary data and accurately determines the distribution of potato tubers in the soil, ideal shape of the ridge and the minimum necessary depth and distance for the planting of Arizona seed potatoes.
\end{abstract}

Key words: potato; potato tubers; distribution in the soil; mathematical model; ridge

\section{IZVLEČEK}

\section{UPORABA MODELA ZA UGOTAVLJANJE RAZPOREDITVE GOMOLJEV KROMPIRJA (Solanum tuberosum L.) V TLEH}

V letu 2015 smo na laboratoriju Biotehniške fakultete Univerze $\mathrm{v}$ Ljubljani preizkusili model za določanje razporeditve gomoljev krompirja v tleh. Praktično vrednost modela pa smo istega leta preizkusili na polju podjetja Zeleni Hit d.o.o. v Ljubljani. Pri preizkusu modela v laboratoriju smo določili korake za opravljanje meritev in opravili analizo rezultatov. Za optimalno določitev razporeditve gomoljev krompirja $\mathrm{v}$ tleh smo nadgradili program, ki sedaj omogoča 3D zajem podatkov. S tem lahko natančno ugotovimo horizontalni, vertikalni in vzdolžni razpon razporeditve gomoljev $\mathrm{v}$ tleh. S pomočjo programa za preračun oblike gomoljev lahko natančno določimo tudi vertikalno pokritost gomoljev ter minimalno oddaljenost od levega ter desnega roba lehe. Določimo lahko tudi center gomoljev, ki je skupaj z maso gomoljev ključen parameter za izračun ploščine ogrinjače. Ob preizkusu modela v laboratoriju smo ugotovili, da je s programi mogoče natančno zajeti podatke ter jih $\mathrm{v}$ programih tudi primerno obdelati. Tudi pri preizkusu modela na poskusnem polju smo na sorti krompirja Arizona spoznali, da je mogoče zajeti vse podatke, ki so potrebni za nadaljnjo obdelavo. $\mathrm{Na}$ podlagi izračunanih podatkov lahko z veliko gotovostjo trdimo, da model omogoča pridobivanje vseh potrebnih podatkov, s katerimi lahko merimo in zanesljivo napovemo razporeditev gomoljev krompirja $\mathrm{v}$ tleh, optimalno obliko lehe ter minimalno potrebno globino in razdaljo sajenja semenskega gomolja krompirja pri sorti Arizona.

Ključne besede: krompir; gomolji; razporeditev gomoljev v tleh; matematični model; leha

\footnotetext{
1 Dr., prof. Biotehniška fakulteta, Jamnikarjeva 101, 1000 Ljubljana, e-pošta: rajko.bernik@bf.uni-lj.si

2 Dr., Biotehniška fakulteta, Jamnikarjeva 101, 1000 Ljubljana, e-pošta: bojan.gospodaric@bf.uni-lj.si

3 Dr., Podkum 69, 1414 Podkum, e-pošta: jost.potrpin@gmail.com

4 Mag.univ.dipl.inž.agr, Kmetijski inštitut Slovenije; Hacquetova 17, 1000 Ljubljana, e-posta:uros.benec@kis.si

5 The program was developed at the Biotechnical Faculty, Department of Agronomy in cooperation with Microsoft programmers within Microsoft .NET initiative in 2002 in object-oriented programming language C\# (C-Sharp).
} 


\section{INTRODUCTION}

Optimal shape of the potato ridge and adequate soil coverage of potato tubers are crucial technological parameters in potato cultivation. Producers are faced with various damages and deformations of potato crop, which are in direct connection with suboptimal formation of the ridges, shallow planting of seed tubers etc (Kouwenhoven, 1967; Kouwenhoven 1970). Inadequate size of potato ridges may lead to potato greening, fungal diseases and other faults on marketable crop (Vučajnk, 2006). Horizontal and vertical distribution of potato tubers differs greatly among potato varieties. Vučajnk (2009) demonstrated the importance of vertical soil cover in his experiments. This parameter is linked to the cross-sectional area of the ridge, planting depth and the time of mechanical soil covering (Vučajnk, 2009). The amount of soil in the ridge also affects soil temperature. The better the vertical soil cover the lower the temperature of the soil surrounding the seed potato. The temperature rises towards the surface of the ridge, which is particularly problematic in summer months. Shallow planting and undersized ridges cause higher soil temperatures, which promote secondary growth of potato tubers and higher percentages of non-marketable potato crop per production area. Similarly, the amount of soil water is reduced towards the surface of the ridge. The lack of moisture (Dolničar et al., 2004) in the soil during seed tuber germination can be a significant problem in potato cultivation. Moreover, smaller vertical soil cover increases the likelihood for development of green tubers and infection with potato blight (Phytophthora infestans (Mont.) de Bary). Contrary, mechanical potato harvesting is facilitated in fields with optimally-formed ridges (Godeša, 2002) and fewer tubers get damaged during the harvest. Knowing the position of tubers in the ridge is therefore extremely important for the development of mechanization, particularly ridgers and harvesters (Hawkins, 1957). Optimal soil cover of potato tubers varies from 5 to $10 \mathrm{~cm}$ (Kouwenhoven et al., 2003). Vučajnk (2006) determined the optimal cross-section area of the ridge in $90 \mathrm{~cm}$ inter-row spacing in range of $1211-1320 \mathrm{~cm}^{2}$. Kouwehoven et al. (2003) proposed minimal cross-sectional ridge area of $900 \mathrm{~cm}^{2}$ for varieties with longer tubers and larger horizontal tuber span. Bugarčič (2000) also stressed the importance of trapezoid cross-section of the ridge, ridge height of 20-25 cm and central location of seed tubers in the potato ridge. The determination of vertical, horizontal and longitudinal span of the ridge is crucial for assessing tuber distribution in the soil. Bernik et al. (2015) demonstrated significant variability in horizontal and vertical tuber distribution among different potato varieties. No measurements on longitudinal distribution have been performed until now. In our research, the existing two-dimensional method of determining the position of the potato tuber in the ridge was upgraded to a three-dimensional method. This way, we obtain accurate information about the expansion of tubers, in the vertical, horizontal and transverse direction. The three-dimensional determination also shows the extreme points of potato expansion, by which we can calculate precisely the complete growth area of the potato tubes in the ridge.

\section{MATERIALS AND METHODS}

A one-year experiment was carried out on the surfaces of the company GREEN HIT d.o.o. in Ljubljana (Slovenia). The soils were defined as silty clay loam. In order to test the practical applicability of the method, the experiment was processed according to the integrated method, which is most present in the farmer's fields. Zeleni Hit produced potatoes in four-year crop rotation. Potatoes were planted in rows of $68 \mathrm{~m}$ long.
The distance between rows was $75 \mathrm{~cm}$. The planting distance in the row was $25 \mathrm{~cm}$. The width of the entire plot was $12 \mathrm{~m}$. The experimental field was fertilized according to the Zeleni hit fertilization plan, which is also used in their potato production. Before planting, we used $1000 \mathrm{~kg} / \mathrm{ha}$ of fertilizer Entec 14-7-7. At hilling, we used $150 \mathrm{~kg}$ of KAN $(27 \% \mathrm{~N})$ and $300 \mathrm{~kg}$ of potassium sulfate (Table 1).

Table 1: Used fertilizers

Tabela 1: Uporabljena gnojila

\begin{tabular}{lcccc}
\hline Fertilizer plan & $\begin{array}{c}\mathrm{N} \\
(\mathrm{kg} / \mathrm{ha})\end{array}$ & $\begin{array}{c}\mathrm{P}_{2} \mathrm{O}_{5} \\
(\mathrm{~kg} / \mathrm{ha})\end{array}$ & $\begin{array}{c}\mathrm{K}_{2} \mathrm{O} \\
(\mathrm{kg} / \mathrm{ha})\end{array}$ & $\begin{array}{c}\mathrm{MgO} \\
(\mathrm{kg} / \mathrm{ha})\end{array}$ \\
\hline Recommended quantities & $100-200$ & $120-150$ & $200-320$ & $60-160$ \\
\hline $\begin{array}{l}\text { 1000 kg ENTEC 14-7-17+ } \mathrm{MgO}+\mathrm{ME} \\
\begin{array}{l}\text { 150 kg KAN 27 \% } \\
\text { 300 kg POTASSIUM SULPHATE 0-0-51 }\end{array}\end{array}$ & 180.5 & 70 & 323 & 23 \\
\hline
\end{tabular}


In the experimental field we used mechanical weed control. We did not use any plant protection products against weeds, pests and pathogens.

In the experiment, we used potato variety Arizona. Arizona is a medium early variety with a yellow skin and light yellow flesh.

The nearest meteorological station is the Ljubljana Bežigrad. The duration of the experiment was from April to August 2015, therefore we use information on average, maximum and minimum temperature and precipitation for the duration of the experiment.

The period from 1.4.2015 to 31.8.2015 was on average about $3{ }^{\circ} \mathrm{C}$ warmer than the long-standing average (Table 2). The biggest deviation was in July, which was just $4.4{ }^{\circ} \mathrm{C}$ warmer than the long-standing average. The smallest difference was in April, when the average temperature was $1.9{ }^{\circ} \mathrm{C}$ higher than the long-term average. In the period from 1.4.2015 to 31.8.2015, the rainfall was $127.9 \mathrm{~mm}$ less than the long-term average (Table 3). The biggest deviation was in April, when $63.2 \mathrm{~mm}$ of rainfall was less than Long-term average. The smallest difference was in July, when there was less than $4 \mathrm{~mm}$ precipitation, which is a long-term average.

From this we can conclude that the spring was not in favor of a good emergence of potatoes, as the moisture in the soil was lacking. Therefore, it was especially important that the soil was well prepared and the planting was carried out optimally. Multiple shortages of precipitation and then their abundance is a major stress for potato growth. This can result in tuber cracking and secondary growth. Strong plates or floods also have a strong impact on the shape of the ridge. In July and August, a period of drought occurred again

Table 2: The average monthly air temperature in 2015, compared to the long-lasting average of the period 19611990 in Ljubljana Bežigrad $\left({ }^{\circ} \mathrm{C}\right)$ (meteo portal, 2015).

Tabela 2: povprečne mesečne temperature zraka v letu 2015 v primerjavi z dolgoletnim povprečjem 1961-1990 za Ljubljano Bežigrad $\left({ }^{\circ} \mathrm{C}\right)$ (Meteo portal, 2015).

\begin{tabular}{lcc}
\hline & Year & Year \\
Month & 2015 & $1961-1990$ \\
\cline { 2 - 3 } & Average Temperature $\left({ }^{\circ} \mathrm{C}\right)$ & Average Temperature $\left({ }^{\circ} \mathrm{C}\right)$ \\
\hline April & 11.8 & 9.9 \\
\hline May & 17 & 14.6 \\
\hline June & 20.6 & 17.8 \\
\hline July & 24.3 & 19.9 \\
\hline August & 22.3 & 19.1 \\
\hline Average & 19.2 & 16.26 \\
\hline
\end{tabular}

Table 3: The average monthly rainfall in the year 2015, compared to the long-lasting average of the period 19611990 in Ljubljana Bežigrad (mm) (Meteo portal, 2015).

Tabela 3: Povprečna količina padavin v letu 2015 v primerjavi z dolgoletnim povprečjem 1961-1990 za Ljubljano Bežigrad (mm) (Meteo portal, 2015).

\begin{tabular}{lcc}
\hline \multirow{2}{*}{ Month } & Year 2015 & Period 1961-1990 \\
\cline { 2 - 3 } & Precipitation $(\mathrm{mm})$ & Precipitation $(\mathrm{mm})$ \\
\hline April & 46.8 & 110 \\
\hline May & 114.9 & 122 \\
\hline June & 150.4 & 155 \\
\hline July & 117.6 & 122 \\
\hline August & 96.4 & 145 \\
\hline Sum & 526.1 & 654 \\
\hline
\end{tabular}

At the beginning we determined individual steps for calculating the distribution of tubers in soil. The steps of the model were as follows:
1: Measurements were taken at several points in the ridge with a measuring device recording threedimensional coordinates (Figure 1.). The device was specifically developed at the Biotechnical Faculty, 
Department of Agronomy. It measures absolute and relative distances in transverse direction in range of $1000 \mathrm{~mm}$, in longitudinal direction in range of $450 \mathrm{~mm}$ and in vertical direction in range of $600 \mathrm{~mm}$. The accuracy of the device is $+/-0.5 \mathrm{~mm}$ in all directions.

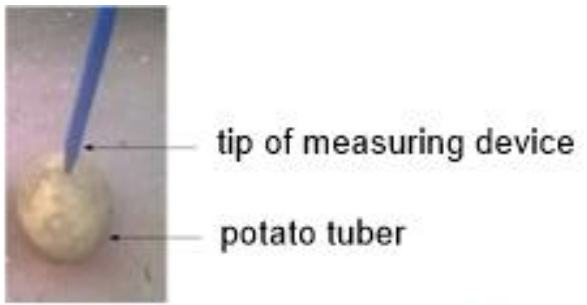



$\mathrm{X}$ measurement

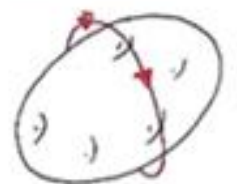

$Y$ measurement

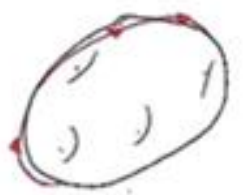

$\mathrm{Z}$ measurement

Figure 1: Three-dimensional measurements of the potato tuber Slika 1: Tri dimenzionalno merjenje gomoljev krompirja

2: The acquired data were elaborated with the use of the program for performing 3D measurements (Figure 2.). The program was developed at the Biotechnical Faculty,
Department of Agronomy and is primarily used for measuring the shape of the ridge and potato tubers in the field (Gospodarič and Fajdiga, 2016).

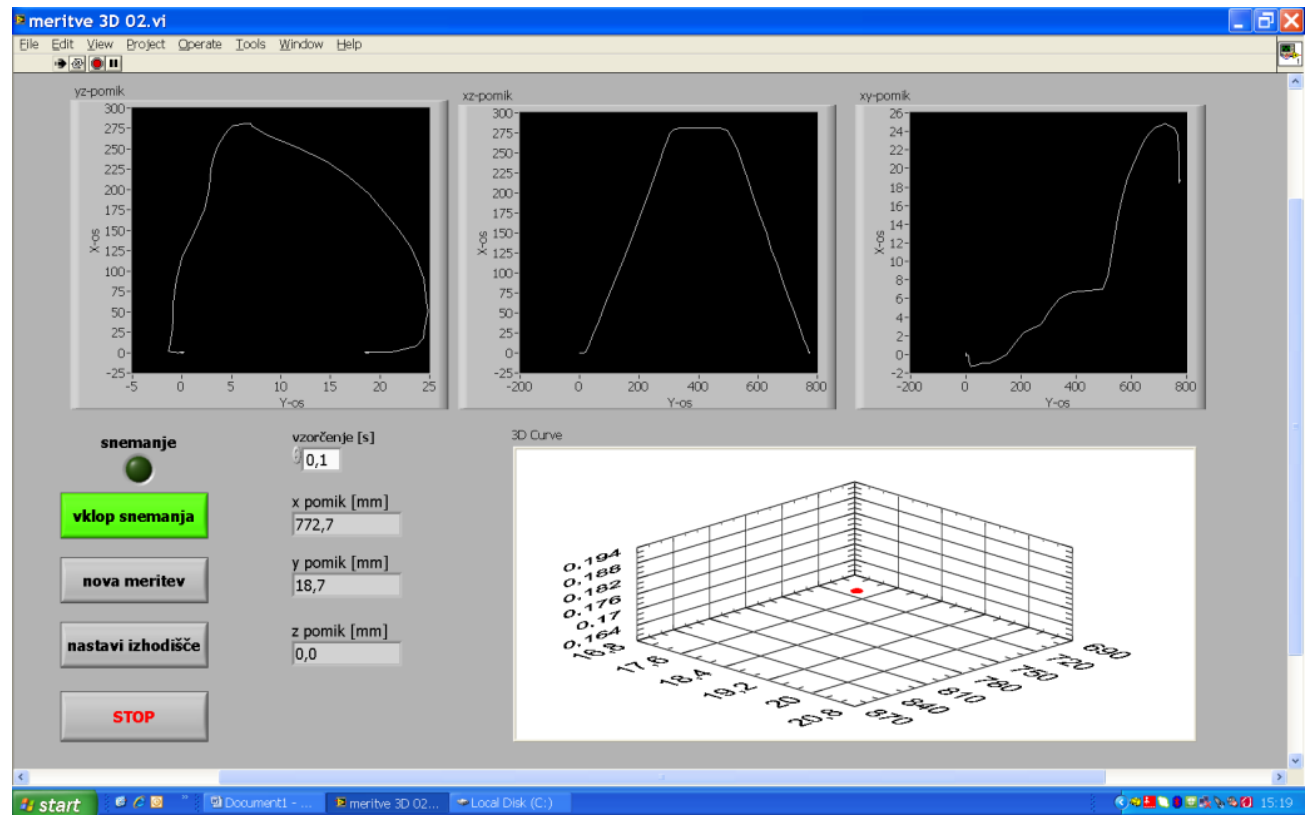

Figure 2: Pop-up window of the 3D measuring program Slika 2: Grafični vmesnik programa 3D merilni program

3: Data were processed in Microsoft Excel and the following parameters were obtained:

- Vertical span of an individual tuber in the soil.

- Horizontal span of an individual tuber in the soil.
- Longitudinal span of an individual tuber in the soil.

- Vertical span defines the maximum distance from the lower to the upper point of the potato tuber. When combining the data of vertical span for all tubers the 
program denotes the span from the lowest point of the lowest tuber to the highest point of the topmost tuber in relation to the height of the ridge. Vertical span of potato tubers is presented on the $\mathrm{Y}$ axis.

- Horizontal span defines the maximum distance from the right to the left edge of a potato tuber. When combining data of horizontal span for all tubers the program denotes the span of tubers situated at the extreme right to the extreme left point in the ridge - perpendicular to the ridge. Horizontal span of potato tubers is presented on the $\mathrm{X}$ axis.

- Longitudinal span defines the maximum distance from the front to the back edge of the potato tuber. When combining the data of longitudinal span for all tubers the program denotes the span of tubers situated at the extreme front to the extreme back in the ridge - longitudinal to the ridge. Longitudinal span of potato tubers is presented on the $\mathrm{Z}$ axis.

- Transformation of data for processing in the 'Calculation of the form and distribution of potato tubers' program.

4: Data processing in the 'Calculation of the form and distribution of potato tubers' program. The program was developed at the Biotechnical Faculty, Department of Agronomy in cooperation with Microsoft programmers within Microsoft .NET initiative in 2002 in objectoriented programming language C\# (C-Sharp). The program requires ».Net» platform version 3.5 because it is written in $\mathrm{C \#}$ version 3.0. After completion of data processing the following output data were acquired:

- Minimum vertical distance of the potato tuber from the edge of the ridge, which corresponds to minimum vertical soil cover of potato tubers.

- $\quad$ Minimum distance of the potato tuber from the left edge of the ridge.
- $\quad$ Minimum distance of the potato tuber from the right edge of the ridge.

- Minimum distance of the potato tuber from the ridge, irrespective of the position.

- Ridge cross-sectional area.

- Transformation of data for processing in a mathematical model enabling calculation of the area surrounding individual tubers (the central point of the tuber is depicted with $\mathrm{x}$; $\mathrm{y}$ coordinates)

5: Calculation of the area surrounding the tuber, which corresponds to the growth space of the potato tuber. The calculation was made with the use of MatLAB mathematical model. Previously employed methods proved insufficiently accurate and therefore, the model was improved in 2012 at the Department of Agronomy, Chair of Phytomedicine, Agricultural Engineering, Crop Production. A compact mathematical model was developed in MatLAB software, which enables the calculation of cross-sectional area of tuber distribution in the ridge (Potrpin and Bernik, 2015). The crosssectional area was termed tuber cluster. The method for tuber cluster assessment is based on a minimum convex polygon (Burgman et al., 2013) and represents the convex area around the potato tuber (Figure 5). The mathematical model also incorporates the volume of potato tubers, which is calculated based on potato mass and density (Cedilnik, 2012). Potrpin and Bernik (2014) performed an experiment for assessing average density of potato tubers and reported insignificant differences in potato density among the studied varieties $\left(1.11 \mathrm{~g} / \mathrm{cm}^{3}\right)$. The value was used in mathematical function along with the mass of individual tubers. First, the position of the tuber in the ridge was recorded and then the tubers were cleaned and weighted. Mathematical model for assessing tuber cluster assumes that the existing volume of the potato is equal to the equivalent volume of the sphere. A corrective parameter may be used to reduce the statistical error as potato tubers are not uniform in shape. 


\section{RESULTS AND DISCUSSION}

Individual steps of the 3D mathematical model for calculation of the distribution of tubers in the ridge were first tested in the laboratory of the Department of Agronomy at the Biotechnical Faculty in Ljubljana. A metal ridge model was prepared based on an ideal shape of the ridge and three potato tubers were placed in the model to test the suitability of the mathematical model.

Three potato tubers were placed across the width of the model ridge for horizontal measurements. For vertical measurements, the potato tubers were placed at different heights in the ridge and for longitudinal measurements the three tubers were placed lengthwise in the model ridge (Figure 3.). Polystyrene foam was placed between the tubers if necessary and only served as a tool, which kept the tubers in the desired position. Positions of individual tubers were recorded and data were processed in specially developed programs.
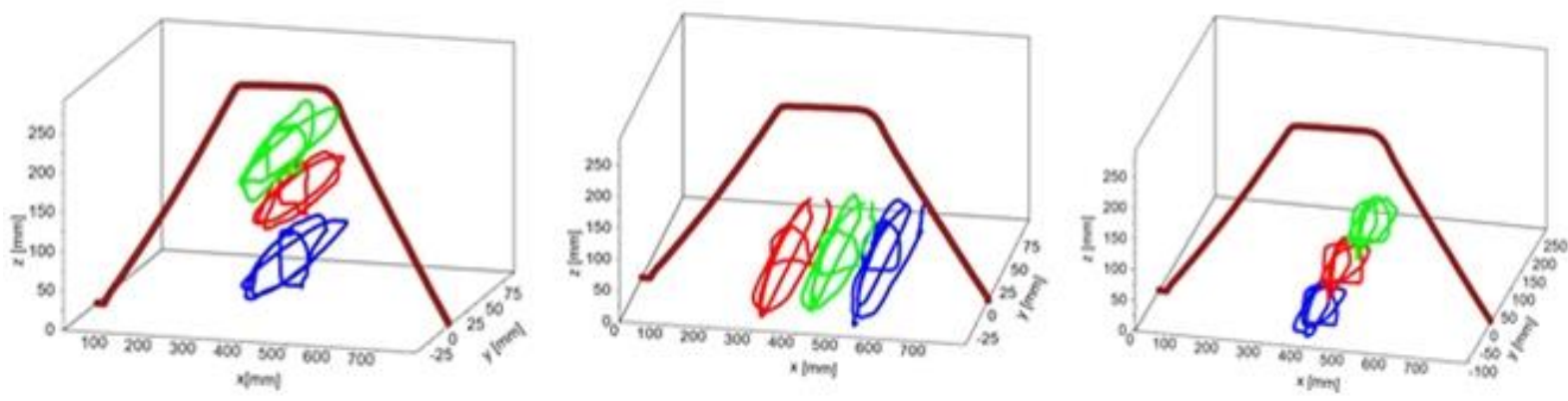

Figure 3: The initial display of the data readings in 3D space

Slika 3: Preliminarne meritve v laboratoriju

The analysis of the results confirmed operational suitability of the device for three-dimensional data acquisition. Recorded data provide all necessary information for determining the distribution of potato tubers in the soil and calculation of tuber cluster area regardless of the position of tubers in the soil (horizontally, vertically or longitudinally to the ridge).

After laboratory measurements a field trial was conducted at ZELENI HIT d.o.o. potato fields located in Ljubljana, Slovenia in order to test the suitability of the method and model in practice. Measurements of potato tuber distribution were recorded before the harvest and all measuring sites were marked with poles. The poles were not moved throughout the experiment and were regarded as reference points (coordinate origin) for all additional measurements at the location. The device was positioned above the site and adjusted to the horizontal position in all directions with the aid of screw spindles. The measuring tip was adjusted to the reference pole and computer readings were recorded. The measuring tip was moved by hand along the surface of the ridge until reaching the opposite side of the ridge. At that point the device was disconnected and a diagram depicting the shape of the ridge appeared on the computer screen. Additionally, the program calculated cross sectional area of the ridge $\left(\mathrm{cm}^{2}\right)$. The distribution of potato tubers in the ridge was also determined with the same measuring device. Average cross-sectional area of the ridge $\left(442.11 \mathrm{~cm}^{2}\right)$ was estimated from the minimum $\left(289.48 \mathrm{~cm}^{2}\right)$ and maximum recorded values $\left(572.41 \mathrm{~cm}^{2}\right)$.

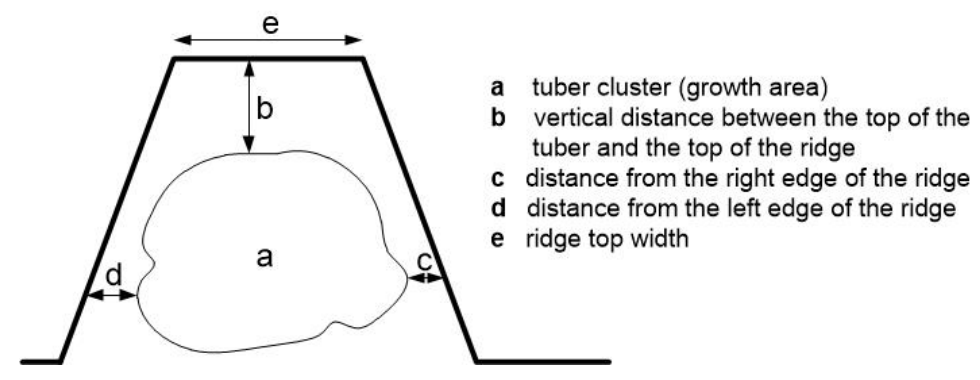

Figure 4: Ridge

Slika 4: Greben (leha) 
Vertical distance denotes the distance between the top of the highest potato tuber and the top of the ridge (Figure 4). Negative values in the tables were ascribed to tubers which were not fully covered by the soil and were subjected to potato greening. Average vertical distance was $-5.3 \mathrm{~mm}$, suggesting that most potato tubers were partly located at the ridge surface. Typically, tubers should be covered with soil at least 5 $\mathrm{cm}$ thick.

Additionally, horizontal, vertical and longitudinal span of potato tubers in the ridge were determined. Average horizontal span of the tubers was $272.67 \mathrm{~mm}$, average vertical span was $119.54 \mathrm{~mm}$ and average longitudinal span in the ridge was $247.77 \mathrm{~mm}$. Based on maximum recorded longitudinal span of 'Arizona' potato tubers it can be concluded that this variety should be planted at higher planting distances of at least $368 \mathrm{~mm}$. Moreover, somewhat higher ridges should be formed for this variety as the maximum recorded vertical span of potato tubers in field experiments was $184 \mathrm{~mm}$. If we add the recommended $50 \mathrm{~mm}$ of soil for optimal potato cover the height of the ridge should be at least $234 \mathrm{~mm}$. The results are in accordance with data reported by Bugarič (2000), who recommended ridge height between 200 and 250 in standard potato production. Optimal ridge top width is in direct connection with suitable soil cover of the tubers and is defined based on the horizontal span of potatoes in the ridge. Ridge top width for Arizona variety should be $28 \mathrm{~cm}$ (Table 1), which corresponds to previous reports of Vučajnk (2009). The mathematical model also enabled the calculation of tuber cluster area in the experimental ridge in the field (Table 1). Tuber cluster area is directly linked to cross-sectional area of the ridge. The larger the tuber cluster area the larger the cross-sectional area of the ridge. Recommended crosssectional area of the ridge for Arizona potatoes was calculated based on maximum tuber cluster area and should be at least $794 \mathrm{~cm}^{2}$. According to the report by Arends and Kus (1999) this is a medium-sized ridge and therefore, at least $75 \mathrm{~cm}$ inter-row spacing should be maintained (Table 4).

Optimal ridge form for the Arizona potato variety was sketched based on the recordings and is presented in Figure 5 and Table 4.

Table 4: Optimal ridge form for the Arizona potato variety

Preglednica 4: Oblika optimalnega grebena za sorto Arizona

\begin{tabular}{ll} 
Recommended inter-row distance (a) & $75 \mathrm{~cm}$ \\
Recommended height of the ridge (v) & $23.4 \mathrm{~cm}$ \\
Recommended ridge top width (c) & $28 \mathrm{~cm}$ \\
Recommended planting distance in the row & $37 \mathrm{~cm}$ \\
\hline
\end{tabular}

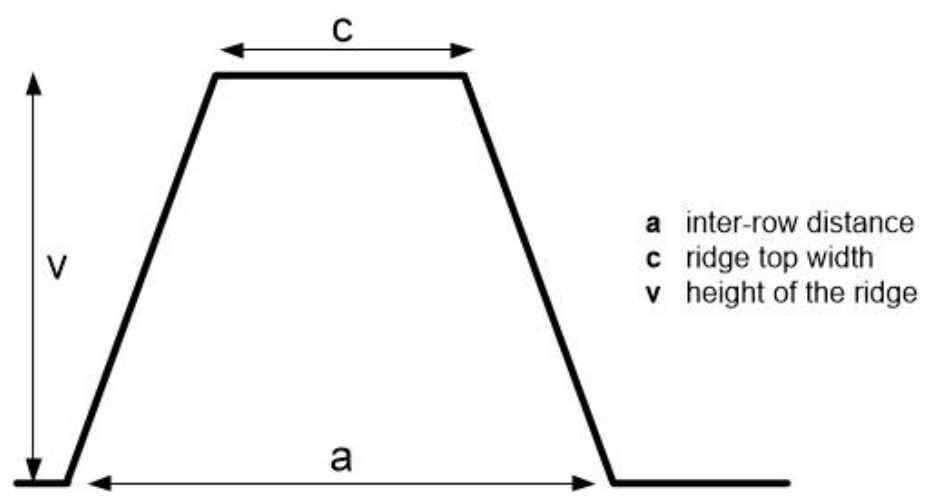

Figure 5: Basic dimensions of the ridge (Benec, 2015)

Slika 5: Greben in razponi (Benec, 2015)

\section{CONCLUSION}

The aim of the experiment was to evaluate the applicability of the mathematical model for determining potato tuber distribution in the soil at field conditions. A coordinate-measuring device was used, a 3D program was upgraded and mathematical model was developed in order to assess the dispersal of tubers in the soil. Most problems, which afflict potato producers derive from inadequate soil cover of potato tubers. Green tubers are 
formed as a result of light exposure. These represent non-marketable potato crop and consequently, a loss in field production capacity and farm economy. 3D model enables detailed determination of potatoes in the soil.
Input data are then used for calculation of horizontal, vertical and longitudinal span of tubers in the soil (Figure 6). Data are available in .txt form and thus suitable for further processing.

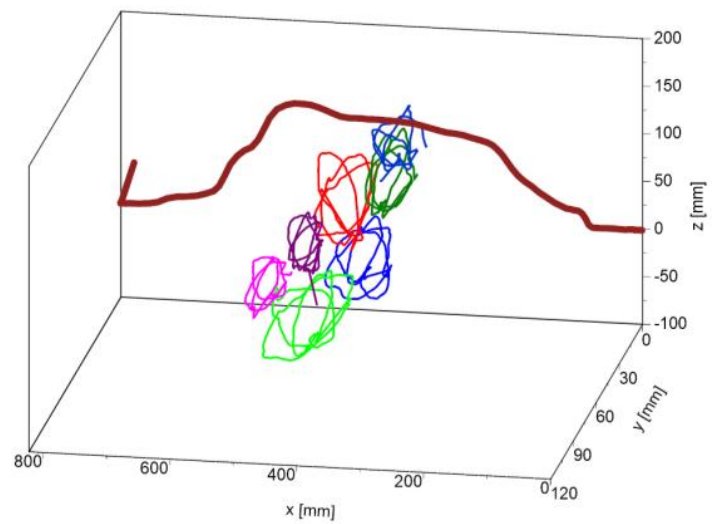

Figure 6: 3D graphics of one of the measuring sites

Slika 6: 3D grafični prikaz enega od merilnih mest

Further data processing in the 'CALCULATION OF THE FORM AND DISTRIBUTION OF POTATO TUBERS' program $^{5}$ determines the minimum vertical distance from the top of the highest tuber to the top of the ridge, tuber distance from the left and right edge of the ridge and its minimal distance from the edge of the ridge. This information is needed for determining optimal ridge form of a specific variety. A sketch of an ideal ridge for Arizona variety is presented in Figure 5. The model also enables recommendation on suitable planting depth and distance, inter-row spacing and other parameters crucial for optimally formed ridges. The data are useful for correct setting of mechanization for specific potato varieties as the distribution of potato tubers can be predicted with adequate certainty. Up to now, no research has been conducted on the effect of different planting techniques (inter-row spacing and planting distance) and weather conditions on potato tuber distribution and the shape of tuber cluster. Therefore, our further studies will be aimed to determine the connections among these factors.

\section{REFERENCES}

Arends P., Kus M. (1999). Nasveti za pridelovanje krompirja $v$ Sloveniji. Kranj, Mercator -KŽK Kmetijstvo Kranj: 241.

Bernik R., Demšar I., Potrpin J. (2015). Growth requirements of different potato cultivars. Plant Soil Environ, 61, 12, 553-559. doi:10.17221/542/2015-PSE

Bugarčić Ž. (2000). Krompir: tehnologija proizvodnje, skladištenje i zaštita. (pp. 50). Beograd, Caligraph.

Burgman M. A., Fox J. (2013). Bias in species range estimates from minimum convex polygons: implications for conservation and options for improved planning. Animal Conservation, 6, 19-28. doi:10.1017/S1367943003003044

Cedilnik A. (2012). Enačba za izračun površine ogrinjače okrog gomoljev krompirja. Ljubljana,
Biotehniška fakulteta (osebna informacija, maj 2012).

Dolničar P., Vučajnk F., Godeša T., Bernik R. (2004). Vpliv stresnih razmer in tehnologije pridelovanja na pojav fizioloških napak na gomoljih krompirja. V: Novi izzivi v poljedelstvu 2004 : zbornik simpozija: proceedings of symposium, Čatež ob Savi, 13. in 14. december 2004. Ljubljana, Slovensko agronomsko društvo, 220-227.

Godeša T. (2002). Določanje oblike grebena pri pridelavi krompirja (Solanum tuberosum L.). V: Novi izzivi v poljedelstvu 2002, Zreče, 5. in 6. dec. 2002. Ljubljana, Slovensko agronomsko društvo: 313-317.

Gospodarič B., Fajdiga G. (2016). 3D meritev gomoljev krompirja v lehi : navodila za program. Univerza $\mathrm{v}$ Ljubljani, Biotehniška fakulteta, oddelek za lesarstvo. 
Hawkins D. (1957). The design of potato harvesters. Journal of Agricultural Engineering Research, 2. 14-24.

Kouwenhoven J.K. (1967). Recent development in potato ridging in the Netherlands. European Potato Journal, 3, 257-271. doi:10.1007/BF02364466

Kouwenhoven J.K. (1970). Yield, grading and distribution of potatoes in ridges in relation to planting depth and ridge size. Potato Research, 13, 59-77. doi:10.1007/BF02355893

Kouwenhoven J.K., Perdok U.D., Jonkheer P.K., Sikkema P.K., Wieringa A. (2003). Soil ridge geometry for green control in French fry potato production on loamy clay soils in The Netherlands. Soil \& Tillage Research, 74, 125-141. doi:10.1016/S0167-1987(03)00149-1

Meteo portal. 2015. Arhiv meritev. Agencija Republike Slovenije http://www.meteo.si/met/sl/app/webmet/\#webmet= $=8 \mathrm{Sdw}$ 2bhR2cv0WZ0V2bvEGcw9ydlJWblR3Lw Vnaz9SYtVmYh9iclFGbt9SaulGdugXbsx3cs9mdl 5WahxXYyNGapZXZ8tHZv1WYp5mOnMHbvZ XZulWYnwCchJXYtVGdlJnOn0UQQdSf; (10.11. 2015)

Potrpin J., Bernik R. (2014). Requirements for the growth with regard to the space in the ridge with different potato cultivars. Journal of Food, Agriculture \& Environment, 12, 1, 1532-1537.

Vučajnk F. (2006). Pridelava krompirja pri različnih medvrstnih razdaljah grebenov in pri uporabi osipalnikov $z$ različnimi načini delovanja. Magistrsko delo. Ljubljana, Biotehniška fakulteta, Oddelek za agronomijo, 197 str.

Vučajnk F. (2009). Novi načini saditve krompirja in oblikovanja grebenov. Doktorska disertacija. Ljubljana, Biotehniška fakulteta, Oddelek za agronomijo, $302 \mathrm{str}$. 